\title{
Bioassessment of Mandakini River with the help of aquatic macroinvertebrates in the vicinity of Kedarnath Wildlife Sanctuary
}

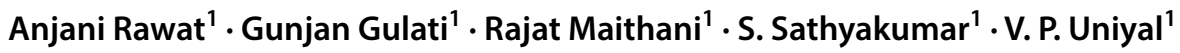

Received: 25 April 2019 / Accepted: 10 December 2019 / Published online: 20 December 2019

(c) The Author(s) 2019

\begin{abstract}
Increasing advancement in development activities in the Indian Himalayan region in tandem with changing climate is influencing the ecological patterns of rivers. Thus, the present study investigates the effect of various degrees of anthropogenic stresses and possible implication of thermal dynamics of river water on the macroinvertebrate community in the Mandakini River, which flows in the vicinity of Kedarnath Wildlife Sanctuary of Chamoli district, Uttarakhand. The main objective was to study the community structure of macroinvertebrates in the Mandakini River and to calculate the effect of anthropogenic stresses on the macroinvertebrate community, particularly on Ephemeroptera, Plecoptera, and Trichoptera. The study was carried out in 10 spatially located sampling stations, and the frequency of sampling was divided into pre- and post-monsoon season (May and November 2017). Based on the degree of anthropogenic stresses, sampling locations were divided into least (Sonprayag), medium (Ukhimath), and high disturbed (Rudraprayag) sites. A total of 3257 individuals belonging to 7 orders and 21 families were found in both the sampling season. Diptera and Trichoptera were dominant orders in both the seasons, whereas Baetidae (Ephemeroptera), Hydropsychidae, Leptoceridae (Trichoptera) and Chironomidae (Diptera) were dominant families. Shannon diversity index varies from 2.048 to 2.25 in the least disturbed site (Sonprayag), 0.186-2.446 in medium disturbance (Ukhimath), and 1.362-2.271 in the highly disturbed site (Rudraprayag) in both the sampling season. Quantification of the EPT index shows a negative trend with an increase in anthropogenic stress, and it was least in Rudraprayag as compared to the other two sites. Result of one-way ANOVA shows a significant difference in diversity between pre- and post-monsoon season $(p<0.05)$. Analyzing the research gaps, it is recommended to have long-term ecological monitoring of high altitude and glacier-fed rivers and streams to obtain robust information regarding the dynamics of the riverine ecosystem in Garhwal Himalayas.
\end{abstract}

Keywords Aquatic macroinvertebrates $\cdot$ EPT $\cdot$ Himalaya $\cdot$ Mandakini $\cdot$ Kedarnath Wildlife Sanctuary

\section{Introduction}

Garhwal Himalayas boasts of its exotic beauty and serenity because of its beatific landscapes and rivers flowing across it. However, with the advancement of the Anthropocene age, every vulnerable ecosystem is influenced by it, especially the aquatic ecosystem. Aquatic macroinvertebrates, which act as a river sentinels, are sensitive to such changes and are used worldwide for evaluating the impact of climate change and anthropogenic stresses. Majority of rivers in Garhwal region are glacier-fed and vary in their ecological

Anjani Rawat

9045rawat.anjani@gmail.com

1 Wildlife Institute of India, Dehradun 248001, India composition with distance from glaciers, their biodiversity decreases as compared to non-glacial rivers as temperature of the former is influenced by the amount of snowmelt and local climatic regimes, whereas latter is more diverse due to less fluctuation in temperature and discharge (Milner et al. 2001). Subsequent studies have been conducted in Southern Alps and Italian glacier-fed streams to quantify the effect of glacier retreat in the macroinvertebrate community (Jacobsen et al. 2014; Hotaling et al. 2017; Scotti et al. 2018). The characteristic feature of glacier-fed rivers and streams is their fluctuation in average monsoonal discharge, daily discharge, temperature, and riparian sediments like cobbles and boulders (Lencioni 2018). Change in land-use and human activities are important factors influencing the macroinvertebrate community (Meyer and Turner 1992), whereas changes in the climatic conditions might be the result of 
the natural process (Parmesan and Yohe 2003). On the one hand, anthropogenic disturbances and land-use patterns are affecting rivers and streams (Carvalho and Tejerina-Garro 2015) and on the other hand meteorological phenomenon such as air temperature and precipitation which has strong correlation with climate change is affecting the temperature and velocity of the same (McGregor et al. 1995; Karl 2003; Milner et al. 2001; Li et al. 2018; Lencioni 2018). An interesting study done in Taizi river at China predicts the cumulative effect of land use and climate change on EPT (Ephemeroptera, Plecoptera, and Trichoptera) indices with structural equation model and Bayesian network, and the results showed that land-use change due to anthropogenic pressure indicated greater effect on their population than climate change ( $\mathrm{Li}$ et al. 2018). Predictions have been made in European countries that with an increase in glacier retreat by recent climate change will result in shift macroinvertebrates community and the same has been supported by the study of Lods-Crozet et al. (2001) in which the colonization of Diamesa spp. of order Chironomidae has been observed in European Glacier-fed streams. Similarly, the Mandakini River, which is one of the glacier-fed rivers of the Garhwal Himalayan region, is also facing constant stress in past decades due to the retreat of Chorabari glacier which might be due to the cumulative effect of climate change and anthropogenic pressure. Increasing population pressure in the Mandakini River is one of the major factors for river water deterioration. According to the 2011 census, there is a percentage increase of $6.58 \%$ of the population observed from the 2001 census as compared to the 2011 census. Thus, multiple factors are influencing the riverine ecosystem of selected locations, which is further affecting the ecological status of the Mandakini River. Cumulative impact of direct and indirect anthropogenic stress in form of greenhouse gas emissions and increase in developmental activities are changing the microclimate regimes which might be an addon to retreating glacier (McGregor et al. 1995; Boon 1988; Brittain and Saltveit 1989), and aquatic macroinvertebrates are the potential indicator of such changes. Their presence and absence reveal the ecological status and water quality of the particular aquatic ecosystem. As glacier-fed rivers, lakes, and streams in the Himalayan region constitute the majority of available freshwater in the world; hence, their monitoring, management, and conservation are essential for long-term sustenance of water resources. Previous studies have been done in India to quantify water quality and its relation to macroinvertebrates. Checklists of orders Ephemeroptera, Plecoptera, Trichoptera, Coleoptera, and Odonata have been developed by the Zoological Survey of India, focusing mainly on their morphological identification (Sivaramakrishnan et al. 2014; Sharma and Chandra 2009; Chandra et al. 2017). In southern India, assessment of the water quality of rivers and streams of Kudremukh National
Park and North Kannada using aquatic macroinvertebrates has been studied (Sivaramakrishnan et al. 1992). In the Garhwal region, studies have been conducted to understand the macroinvertebrate assemblage concerning different forests type, elevation gradient, stream orders, and latitudinal and longitudinal gradient (Mishra 2007, 2012; Mishra and Nautiyal 2011, 2013; Nautiyal et al. 2004). Fragmented studies have been done in the Himalayan region due to the time and geographical constraints, and the gaps have been recognized in the literature review. Although previous studies done on Mandakini River investigate the distribution pattern of aquatic macroinvertebrate near snowline (Semwal and Nautiyal 2009) and dynamics of aquatic insects in different locations of Mandakini River (Goswami and Singh 2017), the effect of anthropogenic pressure on macroinvertebrates has yet not been studied. Hence, it is important to know how macroinvertebrates respond to various degrees of anthropogenic pressures and climatic variations. Thus, the main objective of the study was (1) to quantify the macroinvertebrate assemblage in different locations of Mandakini River in pre- and post-monsoon season, (2) to quantify the changes in EPT percentage with respect to anthropogenic disturbances and (3) changes in diversity of macroinvertebrates in response to anthropogenic disturbances in both the sampling seasons.

\section{Methods}

The Mandakini River is situated near the Kedarnath Wildlife Sanctuary and owes its origin to the Chorabari Glacier (3895 m) located in the Uttarakhand district of Rudraprayag. It is one of the sacred rivers of Uttarakhand as it covers the area of the shrine of Kedarnath and is of great religious significance to people all over the world. The altitude of the catchment area varies from 3507 to $6917 \mathrm{~m}$ above mean sea level (Kansal et al. 2014).

It is one of the sacred rivers of Uttarakhand as it covers the area of the shrine of Kedarnath and is of great religious significance to people all over the world. The altitude of the catchment area varies from 3507 to $6917 \mathrm{~m}$ above the mean sea level (Kansal et al. 2014). It merges with Songanga at Sonprayag (1789 m) and Madmaheshwar Ganga (1278 m) at Ukhimath and finally dislodges to Alaknanda River at Rudraprayag. Besides this, there are several tributaries of Mandakini at different locations of its basin. Mandakini River covers the significant towns adjoining its banks, which comprises of Sonprayag, Ukhimath, and Rudraprayag. Its basin ranges between an elevation of $3800 \mathrm{~m}$ a.s.l from glacier terminus up to glacier head at an elevation of $6420 \mathrm{~m}$ a.s.l (Kumar and Negi 2016). Sporadic studies have been done (Kumar et al. 2018) to quantify the discharge of Mandakini River where the highest discharge was between 6 and 
$12 \mathrm{~m}^{3} / \mathrm{s}$ observed from June to September with the mean monthly daily rainfall of $120-150 \mathrm{~mm}$ (Fig. 1).

\section{Criteria of site selection}

We did a reconnaissance survey in the towns and villages of Kedarnath wildlife sanctuary situated in the bank of River Mandakini. Based on the degree of anthropogenic disturbances, we divided these towns into three categories, namely (1) least disturbed or undisturbed site, (2) medium disturbed sites and (3) maximum disturbed sites as mentioned in Table 1. Approximate distance from human habitation was recorded which ranged from 0 to $5 \mathrm{~km}$.

\section{Data collection and sampling technique}

Macroinvertebrates were collected from 10 spatially located sampling sites. Sampling time was divided into pre-monsoon (May 2017) and post-monsoon season (November 2017).
Each sampling site had ten subplots, consisting of five riffles and five pools. A total of 100 sampling points was extensively searched for 1 min each in $100-\mathrm{m}$ reach of the river, and each sampling plot was of $1 \times 1 \mathrm{~m}^{2}$ dimensions. "Handpicking method" was adopted over the conventional method of "kick sampling" because most of the riparian bed of Mandakini River is composed of cobbles and boulders. Substrates were picked up quickly to collect the relatively fast swimmers (Flotemersch et al. 2017; Hill et al. 2016). The dominant substratum subsamples were pooled to get composite samples. The depth of the sampling point was noticed with the help of a 12-inch metal scale. The temperature was measured by a handheld digital $\mathrm{pH}$ temperature meter. After collection, macroinvertebrates were dislodged into $300 \mu \mathrm{m}$ sieve net tucked in the bucket and again picked by tweezers meticulously for the average of $2 \mathrm{~h}$ and preserved in $70 \%$ ethanol (Singh and Nautiyal 1990) and brought to laboratory at Wildlife Institute of India, Dehradun, for identification up to family level with the aid of inverted microscope. Macroinvertebrates were identified with the help of keys mentioned

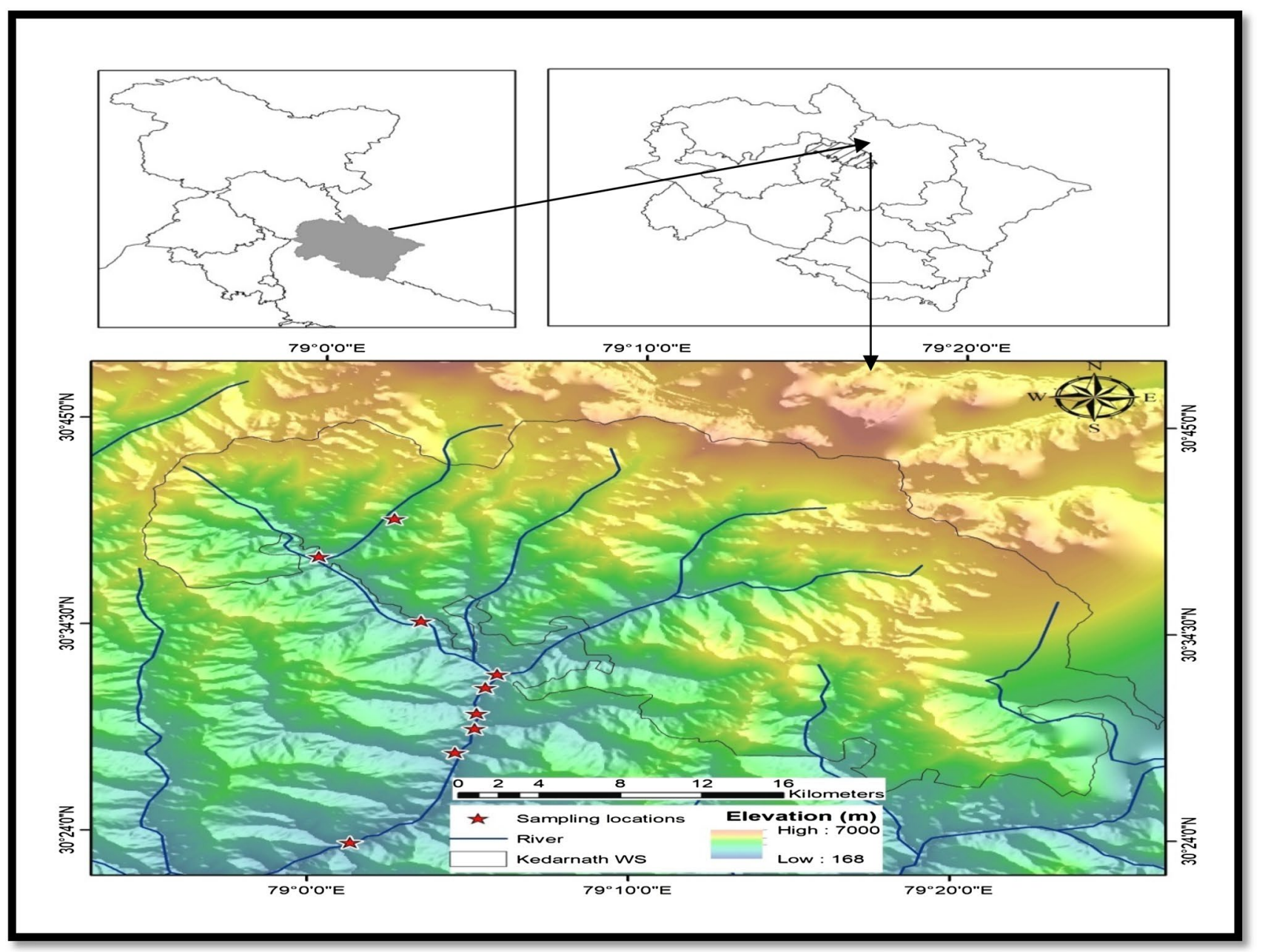

Fig. 1 Map of the sampling sites in Mandakini River, Rudraprayag Uttarakhand, India 
Table 1 Macroinvertebrate sampling location in different areas of Mandakini River

\begin{tabular}{|c|c|c|c|c|c|c|}
\hline Site & Location & $(N=10 /$ site $)$ & Disturbances & $\begin{array}{l}\text { Distance from human } \\
\text { habitation (approx.) }\end{array}$ & Substrate type & $\begin{array}{l}\text { Depth of } \\
\text { collection } \\
\text { (inch) }\end{array}$ \\
\hline 1 & Sonprayag & $\begin{array}{l}\text { Upstream of Gaurikund } \\
(2205 \mathrm{~m})\end{array}$ & Undisturbed & $1-2 \mathrm{~km}$ & Cobbles and stones & $5.2-8.9$ \\
\hline 2 & Sonprayag & $\begin{array}{l}\text { Confluence of Mandakini and } \\
\text { Sonprayag }(1712 \mathrm{~m})\end{array}$ & $\begin{array}{l}\text { Channel alteration/Mass bath- } \\
\text { ing during pilgrimage }\end{array}$ & $0.4-0.7 \mathrm{~km}$ & Cobbles, stones and silt & $3.4-7.8$ \\
\hline 3 & Sonprayag & Kalimath (1321 m) & Occasional landslides & $<5 \mathrm{~km}$ & Cobbles, stones and silt & $3.4-9.3$ \\
\hline 4 & Sonprayag & $\begin{array}{l}\text { Confluence of Madmahesh- } \\
\text { war Ganga and Mandakini } \\
(1108 \mathrm{~m})\end{array}$ & Undisturbed & $<5 \mathrm{~km}$ & Cobbles, stones and silt & $4.4-6.7$ \\
\hline 5 & Ukhimath & $\begin{array}{l}\text { Upper reaches of Ukhimath } \\
\text { Dam }(1054 \mathrm{~m})\end{array}$ & $\begin{array}{l}\text { Road construction and chan- } \\
\text { nel alteration }\end{array}$ & $4-5 \mathrm{~km}$ & Cobbles and stones & $2.3-7.9$ \\
\hline 6 & Ukhimath & Kund (1018) & $\begin{array}{l}\text { Muck disposal and sand } \\
\text { mining }\end{array}$ & $3-4 \mathrm{~km}$ & Cobbles and stones & $4.4-6.7$ \\
\hline 7 & Ukhimath & Kakda $(986$ m) & $\begin{array}{l}\text { Muck disposal, sand mining } \\
\text { and channel alteration }\end{array}$ & $<5 \mathrm{~km}$ & Cobbles and stones & $5.3-6.8$ \\
\hline 8 & Rudraprayag & Bhiri (930 m) & $\begin{array}{l}\text { Sewage sludge disposal, ash } \\
\text { sediments, channel altera- } \\
\text { tion }\end{array}$ & $0.5-0.1 \mathrm{~km}$ & Cobbles and stones & $3.3-5.6$ \\
\hline 9 & Rudraprayag & Agastyamuni (772 m) & $\begin{array}{l}\text { Agricultural runoff, sewage } \\
\text { sludge disposal, muck dis- } \\
\text { posal and road construction }\end{array}$ & $0.2-0.3 \mathrm{~km}$ & Cobbles and stones & $6.4-9.9$ \\
\hline 10 & Rudraprayag & $\begin{array}{l}\text { Rudraprayag Town (Tilwara) } \\
(635 \mathrm{~m})\end{array}$ & $\begin{array}{l}\text { Agricultural runoff, sewage } \\
\text { sludge disposal, muck dis- } \\
\text { posal and road construction }\end{array}$ & $0.2-0.3 \mathrm{~km}$ & Cobbles and stones & $4.9-7.8$ \\
\hline
\end{tabular}

in technical reports, research papers (Subramanian and Sivaramakrishnan 2007; Rana et al. 2017; Chandra 2018). Based on the sensitivity of taxa percentage Ephemeroptera, Plecoptera and Trichoptera were calculated (Hilsenhoff 1982; Cummins and Wilzbach 1985; Crawford and Lenat 1989; Plafkin et al. 1989; Scotti et al. 2018).

\section{Statistical analysis}

Shannon diversity index was calculated using software PAST (3.2). Percentage Ephemeroptera, Plecoptera and Trichoptera (EPT) were calculated using guidelines of Rapid Bioassessment protocol. One-way ANOVA was conducted in XLSTAT (2018) software to find the significant difference between the two seasons.

\section{Result and discussion}

\section{Community structure of aquatic macroinvertebrates}

A total of 7 orders and 21 families and 3214 individuals have been found in pre- and post-monsoon season in different sampling locations of the Mandakini River. A list of aquatic macroinvertebrates found in pre- and post-monsoon season is tabulated in Tables 2 and 3. During pre-monsoon season, Limnephilidae, Leptoceridae, Hydropsychidae, Glossosomatidae, Limoniidae, and Chironomidae were dominant families, whereas in post-monsoon season, Baetidae, Ephemerellidae, Ameletidae, Hydropsychidae, Chironomidae, and Hydrachnid were dominant. Trichoptera (Caddisflies) and Diptera (True Flies) were more abundant order in pre-monsoon, whereas Ephemeroptera and Diptera were more abundant during post-monsoon. According to the zonal distribution of macroinvertebrates among the categorized sites, Limnephilidae, Leptoceridae, Hydropsychidae, Branchycentridae, Glossosomatidae, Limoniidae, and Chironomidae were dominant in Sonprayag area (site 1-4) where forest composition comprised of Quercus spp. and Pinus spp. One of the important families found in the confluence of Mandakini and Madmaheshwar Ganga was Blephariceridae (Horaria sp.) belonging to order Diptera, which is one of the rarest insects studied and found in the region. Similar specimens of the same were recorded from Chamba and Dalhousie of Himachal Pradesh (Tonnoir 1930). At the Ukhimath region, Philopotamidae, Leptoceridae, Glossosomatidae, Simuliidae, and Chironomidae were dominant families. Water penny belonging to the Psephenidae family was found in the lower reaches of Ukhimath at the junction of Khakhra gad and Mandakini River. The area comprises of dense mixed forests where Pinus spp. were dominant vegetation. At Rudraprayag region (site 7-10), the 
Table 2 Macroinvertebrates community composition during pre-monsoon season (May 2017)

Table 3 Macroinvertebrates composition during postmonsoon season (November 2017)

\begin{tabular}{|c|c|c|c|c|c|c|c|c|c|c|}
\hline & Site 1 & Site 2 & Site 3 & Site 4 & Site 5 & Site 6 & Site 7 & Site 8 & Site 9 & Site 10 \\
\hline Baetidae & + & + & + & + & - & - & - & - & - & - \\
\hline Ephemerellidae & + & + & + & + & + & + & + & + & + & + \\
\hline Ameletidae & - & - & - & - & - & - & - & - & - & - \\
\hline Heptageniidae & + & + & + & + & + & + & + & - & - & - \\
\hline Perlidae & + & + & + & + & + & + & - & - & - & - \\
\hline Capniidae & - & - & - & - & - & - & - & - & - & - \\
\hline Nemouridae & + & + & + & - & - & - & - & - & - & - \\
\hline Rhyacophilidae & - & - & - & - & - & - & - & - & - & - \\
\hline Limnephilidae & + & + & + & + & + & + & + & + & - & - \\
\hline Philopotamidae & + & + & + & - & + & - & - & - & - & - \\
\hline Leptoceridae & + & + & + & + & + & + & + & + & - & - \\
\hline Hydropsychidae & + & + & + & + & + & + & + & - & - & - \\
\hline Branchycentridae & + & + & + & + & + & + & - & - & - & - \\
\hline Glossosomatidae & + & + & + & + & + & + & + & + & - & - \\
\hline Blephariceridae & - & - & - & - & - & - & - & - & - & - \\
\hline Limoniinae & + & + & + & + & + & + & + & + & + & + \\
\hline Simuliidae & - & - & - & + & + & + & + & + & + & + \\
\hline Anthricidae & - & - & - & - & - & - & - & - & - & - \\
\hline Chironomidae & + & + & + & + & + & + & + & + & + & + \\
\hline Gyrinidae & - & - & - & - & - & - & - & - & - & - \\
\hline Psephenidae & - & - & - & - & - & + & + & + & - & - \\
\hline Libellulidae & - & + & + & - & - & - & - & - & - & - \\
\hline Hydrachnidia & - & - & - & - & - & - & - & - & - & - \\
\hline
\end{tabular}


dominant families were Limoniidae, Simuliidae, and Chironomidae belonging to order Diptera. The number of macroinvertebrates in all the sites was found more in the postmonsoon season $(n=1814)$ as compared to pre-monsoon season $(n=1400)$. Similar results were obtained at Kund to the confluence of Mandakini and Alaknanda (Goswami and Singh 2017). It is deduced from the above statement that the macroinvertebrates community thrives well during the winter season.

\section{\%EPT variation to anthropogenic disturbances}

The biotic index was calculated based on the presence and absence of EPT (Ephemeroptera, Plecoptera, and Trichoptera), and the results indicated that the EPT percentage was higher in the area of minimum disturbances (Sonprayag) and the lowest in the area of maximum disturbance (Rudraprayag) (Figs. 2, 3). The percentage of pollution intolerant taxa in both the sampling season was highest in Rudraprayag (high disturbance). Order Ephemeroptera, Plecoptera, and Trichoptera thrive well in the undisturbed area where the water is well oxygenated and surrounded by riparian forests are known as "specialists." On the contrary, at medium disturbed sites, the diversity of benthic fauna was maximum and the reason could be due to moderate anthropogenic stress in which specialists could not survive and thus give generalists the opportunity to diversify (He et al. 2018). The fundamental concept behind the biotic index is based on the fact that most genera are sensitive to organic pollution (Rosenbery and Resh 1993; Fierro et al. 2017; Wan Abdul Ghani et al. 2018). During the pre-monsoon season (May 2017), the percentage EPT values range from 69.18 to $82.6 \%$ at a minimum disturbed site (Sonprayag), 51.44 to $64.18 \%$ at a medium disturbed site (Ukhimath) and 11.44 to $44.62 \%$ at the maximum disturbed site (Rudraprayag). Similar results were obtained for the post-monsoon season, where the EPT abundance ranged from 69.18 to $82.6 \%$ at least disturbed site, 40.54 to $64.41 \%$ at medium disturbed sites, and 12.8 to $20.61 \%$ at maximum impaired sites. It can, therefore, be deduced from the above results that the abundance of EPT could vary with seasonal fluctuations and anthropogenic disturbances. The maximum disturbed
Fig. 2 Variation in \%EPT during pre-monsoon season (May, 2017)

Fig. 3 Variation in \%EPT during post-monsoon season (November 2017)
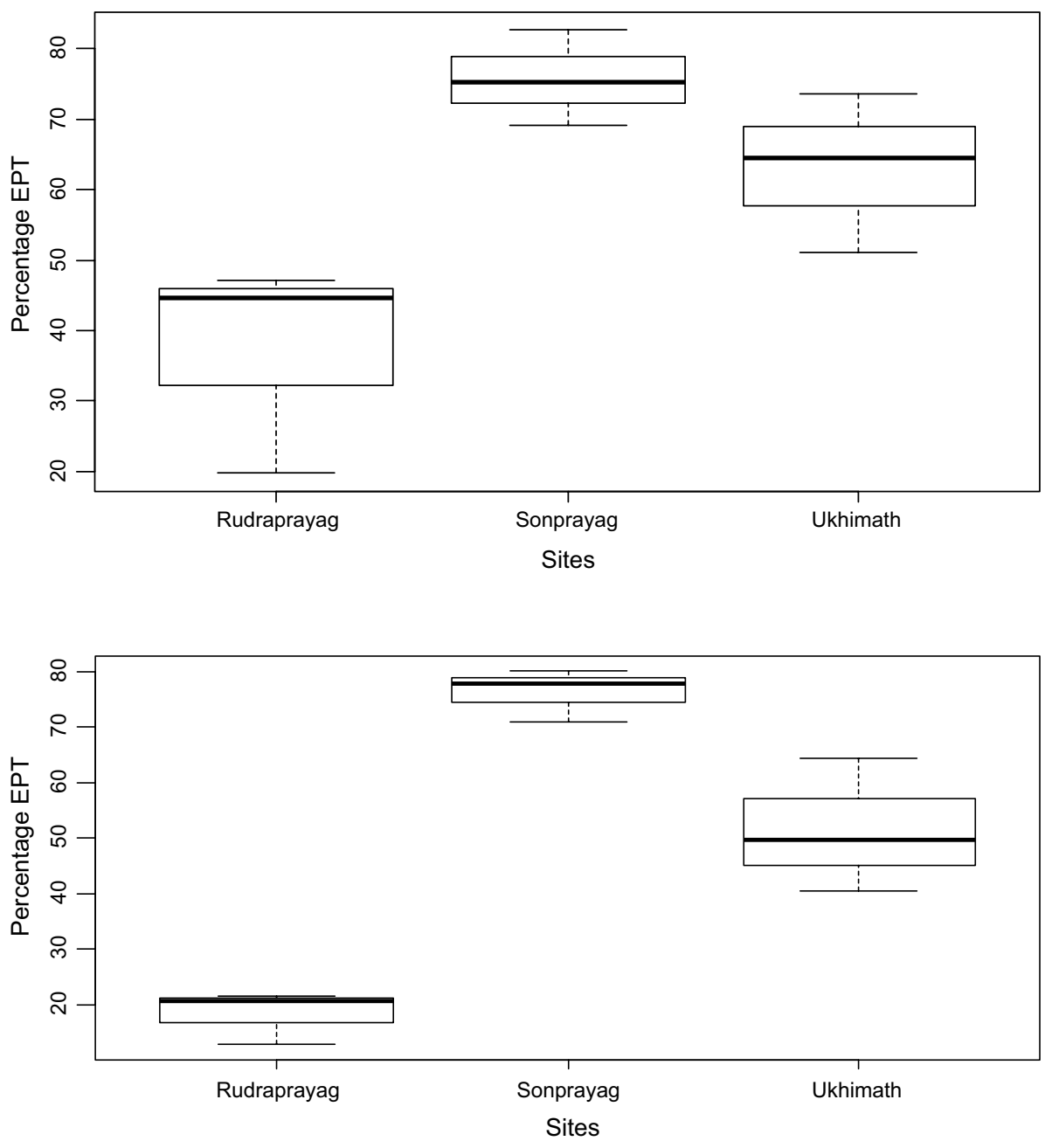
sites (Rudraprayag) had the least abundance of EPTs and a high number of Diptera. As a result, an area with higher anthropogenic disturbances (Rudraprayag) had poor water quality compared to medium (Ukhimath) and minimum disturbance (Sonprayag) area. Decreasing EPT with an increase in disturbance can be explained by the study conducted by Poultan et al. (2015) at Upper Blue River where the macroinvertebrate community is responding to longitudinal changes on the stream condition and loss of EPT was observed at the downstream of the river where the wastewater discharge is high as compared to upstream where there is low or no disturbance. The pattern of land use also plays an important role in structuring the benthic macroinvertebrate population, and thus its impact can be seen in the benthic fauna of these specific landforms if there is an intrusion in the surrounding riparian zone through emission loads (Kasangki et al. 2006, $2008, \mathrm{Li}$ et al.). Variation in water quality due to natural or human-induced intervention also affects the macroinvertebrates community as EPT thrives best on the higher levels of dissolved oxygen and very susceptible to the slightest variation in dissolved oxygen. Physical disturbance such as alteration of channels, sand mining and muck disposal, construction of artificial reservoirs, decomposition of riparian forests and chemical alterations such as dumping of solid and liquid waste and agricultural runoff usually affect macroinvertebrate communities near the watershed and tell a lot about the health of the water body, as the less susceptible species to changes in water quality will vanish from that region (Holt and Miller 2011). They, therefore, serve as an excellent bioindicator of water chemistry changes.

\section{Change in the diversity of macroinvertebrates in response to anthropogenic intervention}

During the pre-monsoon season, the Shannon diversity index varied from 2.048 to 2.137 in the least disturbed sites, 0.186 to 2.245 in medium disturbed sites, and 1.362 to 1.597 in maximum disturbed sites. During the post-monsoon season, the Shannon diversity index ranges between 2.084 and 2.254 at least disturbed sites, 2.245 and 2.446 at medium disturbed sites, and 1.794 and 2.274 at maximum disturbed sites (Fig. 4). Spatial distribution of aquatic macroinvertebrates vis-à-vis their Shannon diversity index was found to be maximum in the moderately disturbed site in both pre- and post-monsoon season in comparison with least and maximum disturbed area. The proportion of specialists to generalists was higher in the Sonprayag area (minimum disturbed), roughly equal in moderately disturbed sites (Ukhimath), and minimum (Rudraprayag) in high anthropogenic disturbances. The reason for such a pattern might be taxonomic groups; EPT is susceptible to the disturbance and changes in stream environment, allowing more tolerant groups to replace them. Consequently, the community assemblage of macroinvertebrates becomes more homogeneous at the disturbed area (Sanchez et al. 2010; He et al. 2018). Other reasons for such fluctuation might be high rainfall, high temperature affecting dissolved oxygen levels, high water velocity in addition to anthropogenic interventions. It is also observed that during pre-monsoon, the disturbance across the lower reaches of the Mandakini River increases due to high tourist influx, which further results in high discharge from nearby localities. These results are consistent with the study conducted by Mehler et al. (2014), at Walker River in the Great Basin Desert, Nevada wherein values of Shannon-Wiener Index $\left(\mathrm{H}^{\prime}\right)$, Margelef's diversity index (DMG) and the Pielou index (J) varied both spatially and temporally and benthic macroinvertebrates communities changed downstream toward depauperate assemblages with a few dominant taxa. However, increased loads of nutrients and other pollutants from agricultural and urban lands are among the dominant stressors that can lead to sharp changes in benthic community structure often associated with land use (De Moor 1992; Cuffney et al. 2000; Cross et al. 2006; Aera et al. 2019).
Fig. 4 Shannon diversity (H') during pre-monsoon (PRM) and post-monsoon season (POM) (May-November 2017)
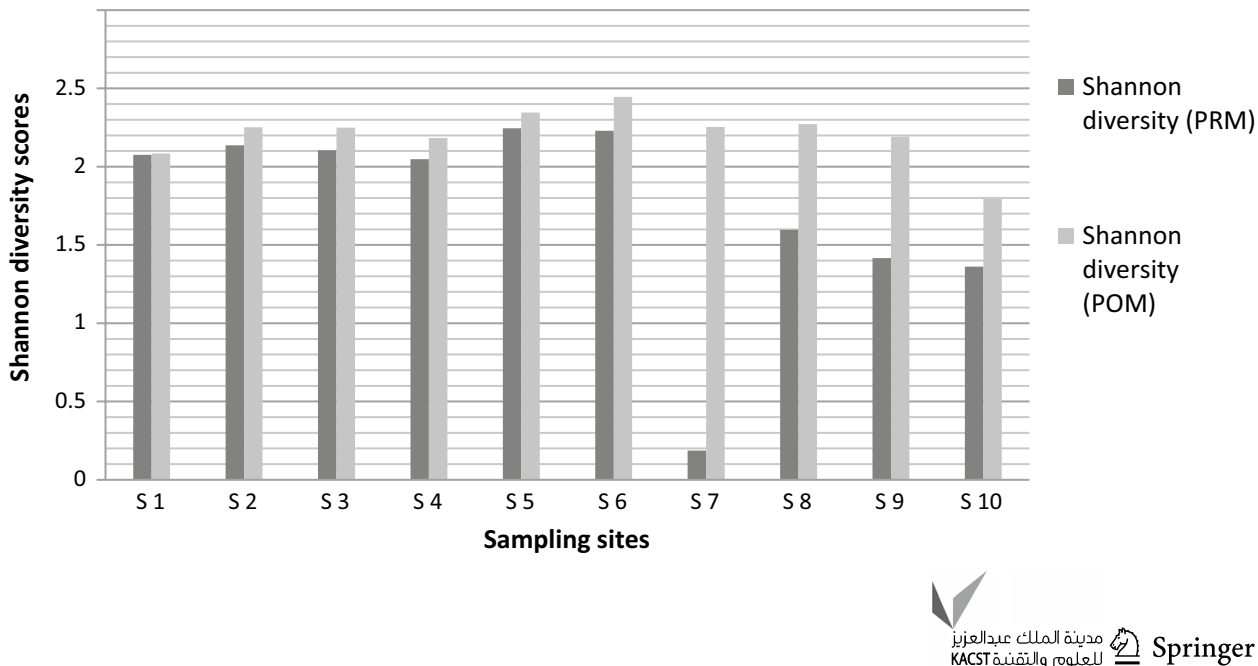
Table 4 Result of one-way ANOVA

\begin{tabular}{llrllll}
\hline Source of variation & SS & $d f$ & MS & $F$ & $p$ value & $F$ crit \\
\hline Between groups & 1.09170 & 1 & 1.091706 & 4.977091 & 0.038645 & 4.413873 \\
Within groups & 3.94823 & 18 & 0.219346 & & & \\
Total & 5.03993 & 19 & & & & \\
\hline
\end{tabular}

\section{Results from one-way ANOVA}

One-way ANOVA was performed on macroinvertebrates diversity to test whether there is any significant difference seasonally in the diversity of aquatic macroinvertebrates. A null and alternate hypothesis was tested to confirm that the diversity of aquatic macroinvertebrates in both pre and postmonsoon season is the same or different. From the ANOVA result, the value of $F$ calculated (4.977) was found to be higher than $F$ critical (4.413), and based on this result, we were able to reject the null hypothesis and accept the alternative hypothesis (Table 4). Further, the $p$ value (0.038) was found to be less than 0.05 , which indicated the level of significance. This result clearly shows that there is a significant difference in the diversity of macroinvertebrates in both the season (i.e., premonsoon, and post-monsoon). However, results show that the value of $p<0.05$ and $\mathrm{F}$ critical value less than the $\mathrm{F}$ calculated value rejecting the null hypothesis. This result indicates the significant difference between the diversity of aquatic macroinvertebrates in pre- and post-monsoon season. Results tabulated in Table 1 clearly show that the ratio of the absence of macroinvertebrates families in pre-monsoon is higher than that of post-monsoon. Also, in Fig. 4, the difference in the diversity indices at the disturbed sites (Site 7, Site 8, Site 9, Site 10) is higher as compared to the other sites, and the diversity index is low in pre-monsoon as compared to post-monsoon season (Righi et al. 2010). The reason for such fluctuation is that during summers (pre-monsoon), the river velocity, temperature, rainfall, and anthropogenic activities are higher as compared to post-monsoon. High temperature is inversely proportional to the dissolved oxygen (Connolly et al. 2004; Buckup et al. 2007; Walczyńska and Sobczyk 2017), which might results in a decrease in the diversity of macroinvertebrates in that region. The results correlate with the studies wherein the anthropogenic and other environmental factors are responsible for the statistically significant difference in macroinvertebrates assemblage seasonally (Kang and King 2013; Sartori et al. 2014; Goswami and Singh 2017; Roy and Homechaudhuri 2017; Verdura et al. 2019; Xue et al. 2019).

\section{Conclusion}

It can be concluded from the above study that the composition of benthic macroinvertebrate varies with the land-use pattern and seasonal changes that affect the hydrology of the Mandakini River.

Analysis of results obtained from the \%EPT index and Shannon diversity indices indicates that compromised water quality at lower Mandakini (Rudraprayag) is due to high anthropogenic disturbance. Selected sites of Ukhimath need proper management and risk analysis to prevent the further impairment of these areas. Results also reveal the statistically significant difference in the diversity of aquatic macroinvertebrates in pre- and post-monsoon, which might indicate the need for proper redressal mechanism for premonsoon when the exposures of anthropogenic influences are high. A high negative correlation of anthropogenic interruptions with the EPT index serves as a model of bioassessment studies in Himalayan Rivers. However, long-term ecological monitoring of high altitude rivers is necessary to quantify climate change effects on benthic fauna. Mandakini River serves as a lifeline for endemic flora and fauna of Kedarnath Wildlife Sanctuary; thus, it is essential to conserve its sanctity.

Acknowledgements The author acknowledges the Director and Dean Wildlife Institute of India for their guidance. We also thank Ms. Nitu Laxmi, Divisional Forest Officer, Kedarnath Wildlife Sanctuary, for providing necessary permission and logistics. We are thankful to Dr. Tapajit Bhattacharya and Mr. Dipak Anand for their valuable comments and review. We highly appreciate the National Mission on Himalayan Studies (NMHS) for providing financial assistance. We are obliged to the reviewers for their constructive comments to improve this manuscript.

Funding Funding was provided by National Mission on Himalayan Studies (Grant No. HJRF010).

\section{Compliance with ethical standards}

Conflict of interest We declare that we have no conflict of interest.

Open Access This article is licensed under a Creative Commons Attribution 4.0 International License, which permits use, sharing, adaptation, distribution and reproduction in any medium or format, as long as you give appropriate credit to the original author(s) and the source, provide a link to the Creative Commons licence, and indicate if changes were made. The images or other third party material in this article are included in the article's Creative Commons licence, unless indicated otherwise in a credit line to the material. If material is not included in 
the article's Creative Commons licence and your intended use is not permitted by statutory regulation or exceeds the permitted use, you will need to obtain permission directly from the copyright holder. To view a copy of this licence, visit http://creativecommons.org/licenses/by/4.0/.

\section{References}

Aera CN, M'Erimba CM, Nzula K (2019) Effect of organic effluents on water quality and benthic macroinvertebrate community structure in Njoro River, Kenya. J Environ Anal Toxicol 9:601. https://doi. org/10.4172/2161-0525.1000601

Boon P (1988) The impact of river regulation on invertebrate communities in the UK. Regul Rivers Res Manag 2(3):389-409. https:// doi.org/10.1002/rrr.3450020314

Brittain J, Saltveit S (1989) A review of the effect of river regulation on mayflies (Ephemeroptera). Regul Rivers Res Manag 3(1):191204. https://doi.org/10.1002/rrr.3450030119

Buckup L, Bueno AAP, Bond-Buckup G, Casagrande M, Majolo F (2007) The benthic macroinvertebrate fauna of highland streams in southern Brazil: composition, diversity and structure. Rev Brasil Zool 24(2):294-301. https://doi.org/10.1590/s0101-81752 007000200005

Carvalho R, Tejerina-Garro F (2015) The influence of environmental variables on the functional structure of headwater stream fish assemblages: a study of two tropical basins in Central Brazil. Neotropical Ichthyol 13(2):349-360. https://doi.org/10.1590/19820224-20130148

Chandra K (2018) Faunal diversity of Indian Himalaya. Zoological Survey of India, Kolkata

Chandra K, Gopi K, Rao D, Valarmathi K, Alfred J (2017) Current status of freshwater faunal diversity in India. Zool Surv India, Kolkata

Connolly NM, Crossland MR, Pearson RG (2004) Effect of low dissolved oxygen on survival, emergence, and drift of tropical stream macroinvertebrates. J N Am Benthol Soc 23(2):251-270. https://doi.org/10.1899/0887-3593(2004)023\%3c0251:eoldo o\%3e2.0.co;2

Crawford JK, Lenat DR (1989) Effects of land use on the water quality and biota of three streams in the piedmont province of North Carolina. US Geological Survey, Water Resources Investigations Report 89-4007, pp 1-67

Cross WF, Wallace JB, Rosemond AD, Eggert SL (2006) Wholesystem nutrient enrichment increases secondary production in a detritus-based ecosystem. Ecology 87(6):1556-1565. https://doi. org/10.1890/0012-9658(2006)87\%5b1556:wneisp\%5d2.0.co;2

Cuffney TF, Meador MR, Porter SD, Gurtz ME (2000) Responses of physical, chemical, and biological indicators of water quality to a gradient of agricultural land use in the Yakima River Basin, Washington. Environ Monit Assess 64:259-270

Cummins K, Wilzbach MA (1985) Field procedures for the analysis of functional feeding groups in stream ecosystems. Contribution No. 1611. Appalachian Environmental Laboratory, University of Maryland, Frostburg, Maryland

De Moor FC (1992) Factors influencing the establishment of aquatic insect invaders. Trans R Soc S Afr 48(1):141-158. https://doi. org/10.1080/00359199209520259

Field Procedures for Analysis of Functional Feeding Groups of Stream Macroinvertebrate (1985) Contributions 1611, Appalachian Environmental laboratory. University of Maryland, Maryland, p 36

Fierro P, Claudio V, Vargas-Chacoff L, Bertrán C, Arismendi I (2017) Macroinvertebrates and fishes as bioindicators of stream water pollution. Water Quality, Hlanganani Tutu, IntechOpen. Available from: https://www.intechopen.com/books/water-quality/ macroinvertebrates-and-fishes-as-bioindicators-of-stream-water -pollution

Flotemersch J, Saavedra J, Laffitte L, Laurenzano B, Bonardi M, Blocksom K (2017) Benthic macroinvertebrate field sampling effort required to produce a sample adequate for the assessment of rivers and streams of Neuquén Province, Argentina. Limnologica 65:55-60. https://doi.org/10.1016/j.limno.2017.05.004

Goswami G, Singh D (2017) Dynamics of aquatic insects in the Mandakini River of Uttarakhand, India. Ecol Environ Conserv 23:331-339

He F, Sun X, Dong X, Cai Q, Jähnig SC (2018) Benthic macroinvertebrates as indicators for river health in Changjiang Basin. Chin Water Syst . https://doi.org/10.1007/978-3-319-97725-6_14

Hill MJ, Sayer CD, Wood PJ (2016) When is the best time to sample aquatic macroinvertebrates in ponds for biodiversity assessment? Environ Monit Assess. https://doi.org/10.1007/s1066 $1-016-5178-6$

Hilsenhoff W (1982) Using a biotic index to evaluate water quality in streams. Wisconsin Department of Natural Resources, Wisconsin, p 22

Holt EA, Miller SW (2011) Bioindicators: using organisms to measure environmental impacts. Nat Educ Knowl 3:8

Hotaling S, Finn D, Joseph Giersch J, Weisrock D, Jacobsen D (2017) Climate change and alpine stream biology: progress, challenges, and opportunities for the future. Biol Rev 92(4):2024-2045. https ://doi.org/10.1111/brv.12319

Jacobsen D, Cauvy-Fraunie S, Andino P, Espinosa R, Cueva D, Dangles $O$ (2014) Runoff and the longitudinal distribution of macroinvertebrates in a glacier-fed stream: implications for the effects of global warming. Freshw Biol 59(10):2038-2050. https://doi. org/10.1111/fwb.12405

Kang SR, King SL (2013) Seasonal comparison of aquatic macroinvertebrate assemblages in a flooded coastal freshwater marsh. Open J Ecol 3(2):30965. https://doi.org/10.4236/oje.2013.32011

Kansal M, Shukla S, Tyagi A (2014) Probable role of anthropogenic activities in 2013 flood disaster in Uttarakhand, India. World Environ Water Resour Congress. https://doi.org/10.1061/97807 84413548.095

Karl T (2003) Modern global climate change. Science 302(5651):1719_ 1723. https://doi.org/10.1126/science. 1090228

Kasangaki A, Babaasa D, Efitre J, McNeilage A, Bitariho R (2006) Links between anthropogenic perturbations and benthic macroinvertebrate assemblages in Afromontane forest streams in Uganda. Hydrobiologia 563(1):231-245

Kasangaki A, Chapman LJ, Balirwa J (2008) Land use and the ecology of benthic macroinvertebrate assemblages of high-altitude rainforest streams in Uganda. Freshw Biol 53(4):681-697

Kumar A, Negi M (2016) Physiographic study of Mandakini valley (Rudraprayag District) Garhwal Himalaya by morphometric analysis and Geospatial Techniques. Int J Geomat Geosci 7(2):128-142

Kumar A, Tiwari SK, Verma A, Gupta AK (2018) Tracing isotopic signatures $(\delta \mathrm{D}$ and $\delta 18 \mathrm{O})$ in precipitation and glacier melt over Chorabari Glacier-Hydroclimatic inferences for the Upper Ganga Basin (UGB), Garhwal Himalaya. J Hydrol Reg Stud 15:68-89. https://doi.org/10.1016/j.ejrh.2017.11.009

Lencioni V (2018) Glacial influence and stream macroinvertebrate biodiversity under climate change: lessons from the Southern Alps. Sci Total Environ 622-623:563-575. https://doi.org/10.1016/j. scitotenv.2017.11.266

Li X, Zhang Y, Guo F, Gao X, Wang Y (2018) Predicting the effect of land use and climate change on stream macroinvertebrates based on the linkage between structural equation modeling and

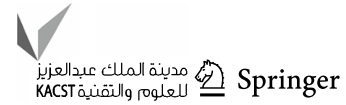


bayesian network. Ecol Ind 85:820-831. https://doi.org/10.1016/j. ecolind.2017.11.044

Lods-Crozet B, Lencioni V, Olafsson J, Snook D, Velle G, Brittain J et al (2001) Chironomid (Diptera: Chironomidae) communities in six European glacier-fed streams. Freshw Biol 46(12):1791-1809. https://doi.org/10.1046/j.1365-2427.2001.00859.x

McGregor G, Petts G, Gurnell A, Milner A (1995) Sensitivity of alpine stream ecosystems to climate change and human impacts. Aquat Conserv Mar Freshw Ecosyst 5(3):233-247. https://doi. org/10.1002/aqc.3270050306

Mehler K, Acharya K, Sada D, Yu Z (2014) Factors affecting spatiotemporal benthic macroinvertebrate diversity and secondary production in a semi-arid watershed. J Freshw Ecol 30(2):197-214. https://doi.org/10.1080/02705060.2014.974225

Meyer W, Turner B (1992) Human population growth and global landuse/cover change. Annu Rev Ecol Syst 23(1):39-61. https://doi. org/10.1146/annurev.es.23.110192.000351

Milner A, Brittain J, Castella E, Petts G (2001) Trends of macroinvertebrate community structure in glacier-fed rivers in relation to environmental conditions: a synthesis. Freshw Biol 46(12):18331847. https://doi.org/10.1046/j.1365-2427.2001.00861.x

Mishra A (2007) Bhagirathi River-an endangered ecosystem, 2018. https://www.researchgate.net/publication/284848195_Bhgirathi_ River-_An_Endangered_Ecosystem

Mishra A (2012) Longitudinal distribution of benthic macroinvertebrate fauna in a Vindhyan river, India. Int J Environ Sci 1948(1):150-158

Mishra A, Nautiyal P (2011) Factors governing longitudinal variation in benthic macroinvertebrate fauna of a small Vindhyan river in Central Highlands ecoregion (Central India), Tropica. Ecologyl 52(1):103-112

Mishra A, Nautiyal P (2013) Longitudinal distribution of benthic macro-invertebrate assemblages in a Central Highlands river, the Tons (Central India). Natl Acad Sci India Sect B Biol Sci 83(1):47-51. https://doi.org/10.1007/s40011-012-0083-4

Nautiyal P, Mishra A, Rawat G, Singh K, Jyoti V, Dwivedi A (2004) Longitudinal variation in the structure of benthic communities in the upland Vindhyan and Himalayan Rivers: river continuum concept approach. Nat J Life Sci 1:85-88

Parmesan C, Yohe G (2003) A globally coherent fingerprint of climate change impacts across natural systems. Nature 421(6918):37-42. https://doi.org/10.1038/nature01286

Plafkin J, Barbour M, Porter K, Gross S, Hughes R (1989) Rapid bioassessment protocols for use in streams and rivers: benthic macroinvertebrates and fish. U.S. Environmental Protection Agency, Washington, DC

Poulton B, Graham J, Rasmussen T, Stone M, Mandy L, Stone M (2015) Responses of macroinvertebrate community metrics to a wastewater discharge in the Upper Blue River of Kansas and Mussouri, USA. J Water Resour Prot 7:15

Rana J, Semalty B, Singh P, Swami N, Dewan S, Singh J et al (2017) Checklist of benthic macroinvertebrate taxa along different riparian land use types in Alaknanda River catchment of the Central Himalaya, Uttarakhand (India). In: Proceedings of the Zoological Society. https://doi.org/10.1007/s12595-017-0241-z

Righi O, Roche F, Froehlich O, Cavallaro R (2010) Structure of macroinvertebrate communities in riffles of a Neotropical karst stream in the wet and dry seasons. Acta Limnol Bras 22(3):306-316

Rosenberg D, Resh V (1993) Freshwater biomonitoring and benthic macroinvertebrates, vol 1. Springer, London, $\mathrm{p} 488$

Roy A, Homechaudhuri S (2017) Comparing the diversity of freshwater macroinvertebrate community along habitat gradients within riverine system in North Bengal, India. J Entomol Zool Stud 5(4):86-93

Sanchez FD, Calosi P, Atfield A, Arribas P, Velasco J, Spicer JI, Bilton DT (2010) Reduced salinities compromise the thermal tolerance of hypersaline specialist diving beetles. Physiol Entomol 35(3):265-273. https://doi.org/10.1111/j.1365-3032.2010.00734.x

Sartori L, Canobbio S, Cabrini R, Fornaroli R, Mezzanotte V (2014) Macroinvertebrate assemblages and biodiversity levels: ecological role of constructed wetlands and artificial ponds in a natural park. jlimnol [Internet]. 27 Nov 2014 [cited 19 Nov 2019], vol 74, no. 2. https://www.jlimnol.it/index.php/jlimnol/article/view/ jlimnol.2014.1018

Scotti A, Jacobsen D, Tappeiner U, Bottarin R (2018) Spatial and temporal variation of benthic macroinvertebrate assemblages during the glacial melt season in an Italian glacier-fed stream. Hydrobiologia 827(1):123-139. https://doi.org/10.1007/s10750-018-3731-8

Semwal V, Nautiyal P (2009) Spatial distribution patterns of benthic macroinvertebrate assemblages in the mountain streams: Mandakini basin-Gangetic Drainage of the western Himalayas. J Hill Res 22(1):21-28

Sharma M, Chandra K (2009) Checklist of Indian Caddisflies (Insecta: Trichoptera). https://www.researchgate.net/publication/23746 0449_CHECKLIST_OF_INDIAN_CADDISFLIES_INSEC TA_TRICHOPTERA

Singh H, Nautiyal P (1990) Altitudinal changes and the impact of municipal sewage on the structure of the river Ganges in the Garhwal Himalaya (India). Acta Hydrobiol 32(3-4):407-421

Sivaramakrishnan KK (1992) Composition and zonation of aquatic insect fauna of kaveri and its tributaries and the identification of insect fauna as indicator of pollution. DOE Project Number 22/18/89-Re. https://scholar.google.co.in/scholar?hl=en\&as_ $\mathrm{sdt}=0,5$ \& cluster $=10150129651567448016$

Sivaramakrishnan K, Subramanian K, Ramamoorthy K, Sharma V, Chandra K (2014) Checklist of ephemeroptera of India. https:// www.researchgate.net/publication/267560499_CHECKLIST_ OF_EPHEMEROPTERA_OF_INDIA

Subramanian KA, Sivaramakrishnan KG (2007) Aquatic insects of India a field guide. Retrieved from: http://wgbis.ces.iisc.ernet.in/ energy/lake2009/workshop/Indian_aqua_Insects.pdf

Tonnoir A (1930) Notes on Indian blepharocerid larvae and pupae with remarks on the morphology of blepharocerid larvae and pupae in general. Records of the Indian Museum. Fauna of India, vol 32, no. 161-214. http://faunaofindia.nic.in/PDFVolumes/recor ds/032/02/0161-0214.pdf

Verdura J, Linares C, Ballesteros E et al (2019) Biodiversity loss in a Mediterranean ecosystem due to an extreme warming event unveils the role of an engineering gorgonian species. Sci Rep 9:5911. https://doi.org/10.1038/s41598-019-41929-0

Walczyńska A, Sobczyk $Ł$ (2017) The underestimated role of temperature-oxygen relationship in large-scale studies on size-totemperature response. Ecol Evol 7(18):7434-7441. https://doi. org/10.1002/ece 3.3263

Wan Abdul Ghani W, Abas Kutty A, Mahazar M, Al-Shami S, Ab Hamid S (2018) Performance of biotic indices in comparison to chemical-based Water Quality Index (WQI) in evaluating the water quality of urban river. Environ Monit Assess. https://doi. org/10.1007/s 10

Xue J, Yang J, Wang Q, Aronson RB, Wu H (2019) Community structure of benthic macroinvertebrates in reclaimed and natural tidal flats of the Yangtze River estuary. Aquac Fish. https://doi. org/10.1016/j.aaf.2019.04.001

Publisher's Note Springer Nature remains neutral with regard to jurisdictional claims in published maps and institutional affiliations. 